\title{
Does Higher Red Blood Cell (RBC) Lactate Transporter Activity Explain Impaired RBC Deformability in Sickle Cell Trait?
}

\author{
Philippe CONNES*, Fagnété SARA*,+, Marie-Dominique HARDY-DESSOURCES ${ }^{\dagger}$, \\ Maryse ETIENNE-JULAN ${ }^{\ddagger}$, and Olivier HUE ${ }^{\star}$ \\ *EA 3596, Laboratoire ACTES, Université des Antilles et de la Guyane, Campus de Fouillole, 97159 \\ Pointe-à-Pitre, Guadeloupe; +UMR S 458 Inserm/Université des Antilles et de la Guyane, CHU \\ Pointe-à-Pitre, Guadeloupe; and ₹Centre Caribéen de la Drépanocytose "Guy Mérault", CHU Pointe- \\ à-Pitre, Guadeloupe
}

\begin{abstract}
Lactate and $\mathrm{H}^{+}$are suggested to promote the sickling process in red blood cells (RBCs) containing hemoglobin S. We demonstrated greater activity of the RBC monocarboxylate cotransporter MCT-1, lower RBC deformability,
\end{abstract}

and impaired hematological indices in sickle cell trait (SCT) carriers compared to control subjects, suggesting an involvement of MCT-1 in hemorheological disturbances in SCT carriers. [The Japanese Journal of Physiology 55: 385-387, 2005]

Key words: hemorheology, sickle cell trait, lactate.

Sickle cell trait (SCT) is the heterozygous form of sickle cell anemia (SCA), which is characterized by the presence of both hemoglobin $\mathrm{A}(\mathrm{HbA})$ and hemoglobin $\mathrm{S}(\mathrm{HbS})$. SCT is usually considered benign and asymptomatic [1], but several studies have introduced doubt about this assumption [2-4]. Two recent studies $[5,6]$ reported impaired red blood cell (RBC) deformability in SCT carriers even though the environmental conditions were normal. Low deformable RBCs may disturb blood rheological properties in microvessels and increase flow resistance [7,8], which adversely affects capillary perfusion. Although never investigated, Smith et al. [9] hypothesized that lactate $/ \mathrm{H}^{+}$uptake could be involved in the sickling process of RBCs containing $\mathrm{HbS}$ because of subsequent dehydration triggered by the activation of the volume- and $\mathrm{pH}$-dependent $\mathrm{K}^{+} / \mathrm{Cl}^{-}$cotransport channels. This may lead to impaired sickle cell rheology and altered blood flow through the microcirculation that could contribute to some of the unexplained cases of health complications in SCT carriers. The major pathway of lactate transport across the RBC membrane is the cotransporter lactate-proton $M C T-1$, which is responsible for $80 \%$ $90 \%$ of the total lactate uptake by RBCs [10], and we recently found higher MCT-1 activity in SCT carriers compared to a control group [11]. Thus on the basis that high MCT-1 activity could lead to high RBC rigidity in SCT carriers, we investigated the relationships between MCT-1 activity (results already published in [11]) and (i) RBC rigidity, (ii) hematological indices such as mean corpuscular volume (MCV) and mean corpuscular hemoglobin concentration (MCHC).

Eight SCT carriers (SCT group, $23.5 \pm 6.9$ yrs, $182.6 \pm 3.5 \mathrm{~cm}, 77.0 \pm 10.3 \mathrm{~kg}$ ) and six subjects with normal hemoglobin (control group, $19.8 \pm 1.3 \mathrm{yrs}$, $178.5 \pm 5.1 \mathrm{~cm}, 70.3 \pm 7.3 \mathrm{~kg}$ ) participated in the study after giving their informed consent. Subjects with hypertension, malaria, and hemoglobinopathy other than SCT were excluded.

After blood sampling, the hemoglobin type was screened by isoelectric focusing, and the results were confirmed by citrate agar electrophoresis. The various hemoglobins were isolated and quantified by highperformance liquid chromatography (HPLC, Hemoglobin Testing System Biorad, Biorad Laboratories, Germany). The presence of $\mathrm{HbS}$ was confirmed by a test of solubility. Positive test results for SCT were determined by the presence of $\mathrm{HbS}$ (less than $50 \%$ ) and

Received on Oct 3, 2005; accepted on Dec 27, 2005; released online on Jan 31, 2006; DOI: 10.2170/jjphysiol.S653 Correspondence should be addressed to: Philippe Connes, Laboratory ACTES (EA 3596) University of the French West Indies Campus of Fouillole 97159 Pointe-à-Pitre Guadeloupe (French West Indies). Phone: +33-6-90-36-76-28, E-mail: pconnes@yahoo.fr 
Table 1. Michaelis-Menten parameters for MCT-1 and hematological and hemorheological parameters in the SCT and control groups.

\begin{tabular}{|c|c|c|}
\hline & SCT group & Control group \\
\hline $\begin{array}{r}V_{\max }\left(\mathrm{nmol} \cdot \mathrm{ml}^{-1} \cdot\right. \\
\left.\quad \text { cells } \mathrm{s}^{-1} \cdot \mathrm{min}^{-1}\right)\end{array}$ & $1,364.9 \pm 392.0^{\dagger}$ & $776.9 \pm 61.6$ \\
\hline$K_{m}(m M)$ & $7.2 \pm 3.2$ & $7.0 \pm 6.1$ \\
\hline$[\mathrm{Hb}]\left(\mathrm{g} \cdot \mathrm{dl}^{-1}\right)$ & $14.7 \pm 0.8$ & $14.3 \pm 0.8$ \\
\hline $\operatorname{MCV}(f \mid)$ & $84.6 \pm 3.8^{+}$ & $92.8 \pm 3.0$ \\
\hline $\mathrm{MCHC}(\mathrm{pg})$ & $35.1 \pm 0.7^{\star}$ & $33.0 \pm 1.9$ \\
\hline$\%$ ret $(\%)$ & $1.0 \pm 0.2$ & $1.3 \pm 0.6$ \\
\hline$[\mathrm{HbA}]$ & $51.5 \pm 1.3^{\dagger}$ & $87.9 \pm 1.2$ \\
\hline$[\mathrm{HbF}]$ & $0.3 \pm 0.3$ & $0.3 \pm 0.3$ \\
\hline [HbA2] & $3.4 \pm 0.3$ & $3.1 \pm 0.3$ \\
\hline$[\mathrm{HbS}]$ & $38.7 \pm 1.6^{\dagger}$ & - \\
\hline$\eta_{b}\left(m P a \cdot s^{-1}\right)$ & $5.94 \pm 0.62^{\star}$ & $5.51 \pm 0.20$ \\
\hline$\eta_{p}\left(\mathrm{mPa} \cdot \mathrm{s}^{-1}\right)$ & $1.69 \pm 0.11$ & $1.72 \pm 0.06$ \\
\hline Hct (\%) & $45.75 \pm 1.96$ & $46.79 \pm 0.72$ \\
\hline$T_{\mathrm{k}}$ & $0.86 \pm 0.03^{+}$ & $0.80 \pm 0.03$ \\
\hline
\end{tabular}

Values are means $\pm \mathrm{SD} . V_{\max }$, maximal lactate transport capacity for MCT-1; $K_{m}$, constant of Michaelis-Menten for MCT-1; $[\mathrm{Hb}$, hemoglobin concentration; MCV, mean corpuscular volume; $\mathrm{MCHC}$, mean corpuscular hemoglobin concentration; \% ret, percentage of reticulocytes; [HbA], concentration of hemoglobin $\mathrm{A} ;[\mathrm{HbF}]$, concentration of hemoglobin $\mathrm{F} ;[\mathrm{HbA} 2]$, concentration of hemoglobin A2; $[\mathrm{HbS}]$, concentration of hemoglobin $S ; \eta_{b}$, blood viscosity; $\eta_{\mathrm{p}}$, plasma viscosity; Hct, hematocrit; $T_{\mathrm{k}}$, coefficient of red blood cell rigidity. Difference between the two groups, ${ }^{*} P<$ $0.05 ;{ }^{\dagger} P<0.01$.

a normal percentage of $\mathrm{HbA} 2$. The following hematological parameters were automatically determined (Max M-Retic, Coulter, USA): hemoglobin concentration ([Hb]), MCV, MCHC, and percentage of reticulocytes (\%ret). The MCT-1 activity of SCT carriers and the control group was determined in a previous study (see [11]). In brief, MCT-1 activity was deduced from the difference between total lactate transport activity and the lactate transport activity determined with the use of $1 \mathrm{mM}$ of p-chloromercuribenzenesulfonic acid (PCMBS) to block the MCT-1. The influx of lactate into washed RBCs was measured by a radioactive tracer technique using $\left[{ }^{14} \mathrm{C}\right]$ lactate (sodium salt, specific activity of $50 \mu \mathrm{Ci} / \mathrm{mM}$ ) at four lactate concentrations $(1.6,8.1,41$, and $81.1 \mathrm{mM})$. The MichaelisMenten coefficients for MCT-1, i.e., the constant of Michaelis-Menten $\left(K_{\mathrm{m}}\right)$ and the maximal lactate transport capacity $\left(V_{\max }\right)$, were determined by curve fitting using GraphPad prism 4 (USA). Blood viscosity $\left(\eta_{b}\right)$ and plasma viscosity $\left(\eta_{p}\right)$ were determined by using a cone plane viscometer (Brookfield DVII+, with CPE40 spindle) at a shear rate of $225 \mathrm{~s}^{-1}$ and at $25^{\circ} \mathrm{C}$.
Hematocrit (Hct) was measured by a micromethod after blood microcentrifugation (HEMA-C, Jouan, France). The index of RBC rigidity (Tk) from Dintenfass $[5,12,13]$ was calculated at high shear rate $(225$ $\left.\mathrm{s}^{-1}\right)$ according to the following equation: $T_{\mathrm{k}}=\left(\eta_{\mathrm{r}}^{0.4}\right.$ $-1) /\left(\eta_{\mathrm{r}}^{0.4} \cdot\right.$ Hct $)$ where $\eta_{\mathrm{r}}$ is relative blood viscosity $\left(\eta_{\mathrm{b}} / \eta_{\mathrm{p}}\right)$ measured at $225 \mathrm{~s}^{-1}$.

We used the $T_{\mathrm{k}}$ index as a deformability index, such as high $T_{\mathrm{k}}$ value indicates low RBC deformability (i.e., high $\mathrm{RBC}$ rigidity).

All results are expressed as means \pm SD. Hematological, hemorheological, and Michaelis-Menten coefficient parameters were compared, using the nonparametric Mann-Whitney test. A two-way analysis of variance (group $\times$ concentrations) for repeated measures was used to compare the MCT-1 activity at the four lactate concentrations between the two groups. Pairwise contrasts were used when necessary to determine where significant differences occurred. A Spearman correlation was performed between the $V_{\text {max }}$ and $T_{\mathrm{k}}, \mathrm{MCV}$, and MCHC. Statistical significance was established at $P=0.05$.

As already reported in a recent study [11], MCT-1 activity was higher in the SCT group than in the control group at $1.6 \mathrm{mM}(P<0.05), 41 \mathrm{mM}(P<0.05)$, and $81.1 \mathrm{mM}(P<0.01)$ (see [11] for more details). No difference was observed between the two groups at 8.1 $\mathrm{mM}$. Although we found no difference for the $K_{\mathrm{m}}$ between them, we found higher $V_{\max }$ in the SCT carriers (Table 1). These results suggest overexpressed MCT-1 in the RBC membranes from SCT carriers, but confirmation by Western blot is needed. The reason for the greater MCT-1 activity in the SCT group is unknown, but it may be related to the occurrence of repeated episodes of hypoxia/hypoxemia in SCT carriers because hypoxemia is known to influence MCT-1 activity and/or expression in humans [11, 14-16]. The higher MCT-1 activity in the SCT group was accompanied by higher RBC rigidity (Table 1). Although hematological values were in the normal range for both groups (no hypochromic microcytosis), MCV was lower and MCHC greater in the SCT carriers. This could be a reflection of the dehydration of RBCs, which might in turn affect RBC deformability [17]. The poor RBC deformability observed in the SCT group led to higher $\eta_{b}$, even though $\eta_{p}$ and Hct did not differ between the two groups (Table 1). Impaired RBC deformability and high $\eta_{b}$ are able to cause blood flow structuring disorders in both the microcirculation and the macrocirculation $[7,8]$, and this might explain the reported health complications in SCT carriers $[3,4]$. The significant correlation between $V_{\max }$ and $T_{\mathrm{k}}$ (Fig. 1, $\rho=0.87 ; P$ 


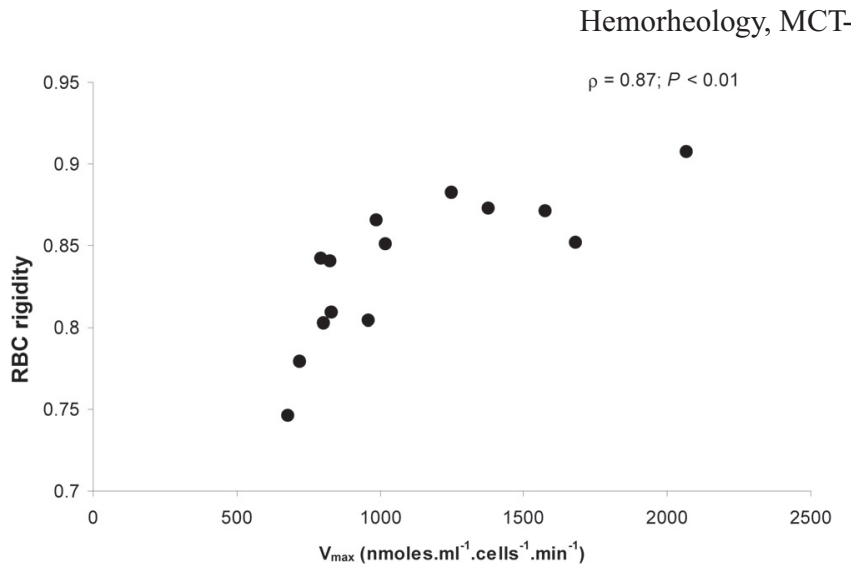

Fig. 1. Relationship between red blood cell rigidity $\left(T_{k}\right)$ and the $V_{\max }$ of MCT-1 $(\rho=0.87 ; P<0.01)$.

$<0.01$ ) suggests an influence of MCT-1 activity upon RBC deformability. Several studies observed that lactate impairs RBC deformability in healthy subjects [9, 13]. Indeed, the greater the MCT- 1 activity, the greater the amount of lactate accumulates into RBCs, leading to impaired RBC deformability. The $V_{\max }$ was also correlated with $\mathrm{MCV}(\rho=-0.73 ; P<0.01)$ and $\mathrm{MCHC}$ $(\rho=0.59 ; P<0.05)$. Altogether, these results suggest that MCT-1 might regulate the deformability of RBCs, maybe via an effect on the dehydration process, as initially hypothesized by Smith et al. [9]. Recent results published by Pattillo and Gladden [16] suggest the same kind of mechanism in sickle cell anemia (HbSS genotype) because they observed high RBC' MCT-1 activity in these patients, and it is well known that RBC deformability from them is altered [18]. In conclusion, our results suggest a role of the MCT-1 protein in the sickling process and in the regulation of RBC deformability in SCT carriers. These alterations in blood rheology might have detrimental effects on blood microcirculation that will increase the risk for cardiovascular complications or vaso-occlusive events in this population.

\section{REFERENCES}

1. Eaton WA and Hofrichter J: Sickle cell hemoglobin polymerization. Adv Protein Chem 40: 63-279, 1990

2. Hiruma H, Noguchi CT, Uyesaka N, Schechter AN, and Rodgers GP: Contributions of sickle hemoglobin polymer and sickle cell membranes to impaired filterability. Am J Physiol 268: 2003-2008, 1995

3. Jones SR, Binder RA, and Donowho EM Jr: Sudden death in sickle-cell trait. N Engl J Med 282: 323-325, 1970
4. Kark JA, Posey DM, Schumacher HR, and Ruehle CJ: Sickle-cell trait as a risk factor for sudden death in physical training. N Engl J Med 317: 781-787, 1987

5. Monchanin G, Connes P, Wouassi D, Francina A, Djoda B, Banga PE, Owona FX, Thiriet P, Massarelli R, and Martin C: Hemorheology, sickle cell trait, and $\alpha$-thalassemia in athletes: Effects of exercise. Med Sci Sports Exerc 37: 1086-1092, 2005

6. Brandao MM, Fontes A, Barjas-Castro ML, Barbosa LC, Costa FF, Cesar CL, and Saad ST: Optical tweezers for measuring red blood cell elasticity: application to the study of drug response in sickle cell disease. Eur J Haematol 70: 207-211, 2003

7. McHedlishvili G and Maeda N: Blood flow structure related to red cell flow: determinant of blood fluidity in narrow microvessels. Jpn J Physiol 51: 19-30, 2001

8. Baskurt OK and Meiselman $\mathrm{HJ}$ : Blood rheology and hemodynamics. Semin Thromb Hemost 29: 435-450, 2003

9. Smith JA, Telford RD, Kolbuch-Braddon M, and Weidemann $\mathrm{MJ}$ : Lactate/ $\mathrm{H}^{+}$uptake by red blood cells during exercise alters their physical properties. Eur J Appl Physiol Occup Physiol 75: 54-61, 1997

10. Deuticke B, Beyer E, and Forst B: Discrimination of three parallel pathways of lactate transport in the human erythrocyte membrane by inhibitors and kinetic properties. Biochim Biophys Acta 684: 96-110, 1982

11. Sara $F$, Connes $P$, Hue $O$, Montout-Hedreville $M$, Etienne-Julan M, and Hardy-Dessources MD: Faster lactate transport across red blood cell membrane in sickle cell trait carriers. J Appl Physiol 2005

12. Dintenfass L: Red cell rigidity, "Tk", and filtration. Clin Hemorheol 5: 241-244, 1985

13. Connes P, Bouix D, Py G, Préfaut C, Mercier J, Brun JF, and Caillaud C: Opposite effects of in vitro lactate on erythrocyte deformability in athletes and untrained subjects. Clin Hemorheol Microcirc 31: 311-318, 2004

14. Juel C, Lundby C, Sander M, Calbet JA, and Hall G: Human skeletal muscle and erythrocyte proteins involved in acid-base homeostasis: adaptations to chronic hypoxia. J Physiol 548: 639-648, 2003

15. Connes P, Bouix D, Py G, Caillaud C, Kippelen P, Brun JF, Varray A, Prefaut C, and Mercier J: Does exerciseinduced hypoxemia modify lactate influx into erythrocytes and hemorheological parameters in athletes? J Appl Physiol 97: 1053-1058, 2004

16. Pattillo RE and Gladden LB: Red blood cell lactate transport in sickle disease and sickle cell trait. J Appl Physiol: [Epub ahead of print], 2005

17. Temiz A, Baskurt OK, Pekcetin C, Kandemir F, and Gure A: Leukocyte activation, oxidant stress and red blood cell properties after acute, exhausting exercise in rats. Clin Hemorheol Microcirc 22: 253-259, 2000

18. Chien S, Usami S, and Bertles JF: Abnormal rheology of oxygenated blood in sickle cell anemia. J Clin Invest 49: 623-634, 1970 